\title{
Assessing blue and green water utilisation in wheat production of China from the perspectives of water footprint and total water use
}

\author{
X. C. Cao ${ }^{1,2}$, P. T. Wu ${ }^{1,2}$, Y. B. Wang ${ }^{1}$, and X. N. Zhao ${ }^{2}$ \\ ${ }^{1}$ College of Water Resources and Architectural Engineering, Northwest A \& F University, Yangling, Shaanxi, 712100, China \\ ${ }^{2}$ Institute of Water Saving Agriculture in Arid regions of China, Northwest A \& F University, Yangling, \\ Shaanxi, 712100, China
}

Correspondence to: P. T. Wu (gjzwpt@ vip.sina.com)

Received: 22 November 2013 - Published in Hydrol. Earth Syst. Sci. Discuss.: 14 January 2014

Revised: 12 July 2014 - Accepted: 21 July 2014 - Published: 25 August 2014

\begin{abstract}
The aim of this study is to estimate the green and blue water footprint (WF) and the total water use (TWU) of wheat crop in China in both irrigated and rainfed productions. Crop evapotranspiration and water evaporation loss are both considered when calculating the water footprint in irrigated fields. We compared the water use for per-unit product between irrigated and rainfed crops and analyzed the relationship between promoting the yield and conserving water resources. The national total and per-unit-product WF of wheat production in 2010 were approximately $111.5 \mathrm{Gm}^{3}$ (64.2\% green and $35.8 \%$ blue) and $0.968 \mathrm{~m}^{3} \mathrm{~kg}^{-1}$, respectively. There is a large difference in the water footprint of the per-kilogram wheat product (WFP) among different provinces: the WFP is low in the provinces in and around the Huang-Huai-Hai Plain, while it is relatively high in the provinces south of the Yangtze River and in northwestern China. The major portion of WF (80.9\%) comes from irrigated farmland, and the remaining $19.1 \%$ is rainfed. Green water dominates the area south of the Yangtze River, whereas low green water proportions are found in the provinces located in northern China, especially northwestern China. The national TWU and total water use of the per-kilogram wheat product (TWUP) are $142.5 \mathrm{Gm}^{3}$ and $1.237 \mathrm{~m}^{3} \mathrm{~kg}^{-1}$, respectively, containing approximately $21.7 \%$ blue water percolation $\left(\mathrm{BW}_{\mathrm{p}}\right)$. The values of WFP for irrigated $\left(\mathrm{WFP}_{\mathrm{I}}\right)$ and rainfed $\left(\mathrm{WFP}_{\mathrm{R}}\right)$ crops are 0.911 and $1.202 \mathrm{~m}^{3} \mathrm{~kg}^{-1}$, respectively. Irrigation plays an important role in food production, promoting the wheat yield by $170 \%$ and reducing the WFP by $24 \%$ compared to those of rainfed wheat production. Due to the low irrigation efficiency, more water is needed per kilogram in irrigated farmland in many arid regions, such
\end{abstract}

as the Xinjiang, Ningxia and Gansu Provinces. We divided the 30 provinces of China into three categories according to the relationship between the TWUP (TWU for per-unit product in irrigated farmland) and TWUP $\mathrm{R}_{\mathrm{R}}$ (TWU for perunit product in rainfed farmland): (I) $\mathrm{TWUP}_{\mathrm{I}}<\mathrm{TWUP}_{\mathrm{R}}$, (II) TWUP $_{I}=$ TWUP $_{R}$, and (III) TWUP $>$ TWUP $_{R}$. Category II, which contains the major wheat-producing areas in the North China Plain, produces nearly $75 \%$ of the wheat of China. The double benefits of conserving water and promoting production can be achieved by irrigating wheat in Category I provinces. Nevertheless, the provinces in this category produce only $1.1 \%$ of the national wheat yield.

\section{Introduction}

China is not only the most populous and the largest foodconsuming country, it is also one of the poorest countries in terms of individual water resources, at only $2100 \mathrm{~m}^{3}$ per capita in 2010 (MWR, 2011), or less than one-quarter of the worldwide water resources per capita (Ge et al., 2011). With the population surge and socioeconomic development, the water crisis has become a hot spot all over the nation because the gap between increased demands and limited water resources is increasing. Meanwhile, agriculture is the largest water user in China, accounting for more than $60 \%$ of the total water (blue water) withdrawals (MWR, 2011). Currently, due to bottlenecks in technology and management, agricultural irrigation water is used with low efficiency and is significantly wasted. It is important to reduce the water use in 
agriculture to meet the freshwater challenges facing China in the future (Wu et al., 2010).

The concept of "water footprint" was introduced by Hoekstra (2003) and offers a new approach to assessing water resource utilisation in agricultural production. The water footprint of a crop product is defined as the volume of freshwater that is consumed during the crop production process. Normally, the water footprint has three components: blue, green and gray water footprints. The blue water footprint refers to the consumption of blue water resources (surface and groundwater) throughout the supply chain of a product; the green water footprint refers to the consumption of rainwater insofar as it does not become run-off; and the gray water footprint refers to the volume of freshwater that is required to assimilate the load of pollutants given natural background concentrations and existing ambient water quality standards (Hoekstra et al., 2011). The water footprint of a crop product is usually measured in two ways: the total water footprint in a specific region $\left(\mathrm{in}^{3}\right.$ ) and the water footprint of a unit mass of product (in $\mathrm{m}^{3} \mathrm{~kg}^{-1} \mathrm{or} \mathrm{m}^{3} \mathrm{t}^{-1}$ ). The total water footprint links itself directly to water resource availability, and the green and blue water footprints of unit production reflect the regional water productivity.

Wheat is one of the three most important grain crops in China. The sown area of wheat was approximately 24.26 million ha, and the yield was 115.18 million $\mathrm{t}$ in 2010 , contributing approximately $17.8 \%$ of the worldwide production (NBSC, 2011). Wheat includes spring wheat and winter wheat based on the growing period. Winter wheat is planted in most provinces of China, while spring wheat is planted mainly in Heilongjiang, Neimenggu, Qinghai, Ningxia and Xinjiang. A number of studies have been published in the past decade on the water footprint of wheat production. Hoekstra and Hung (2005), Hoekstra and Chapagain (2007) and Chapagain et al. (2006) globally evaluated the water use in wheat production during the periods of 1995-1999 and 1997-2001 without distinguishing between green and blue water consumption. Liu et al. (2007a) and Liu (2009) globally estimated the water consumption and its blue and green water distinction in wheat production in 2000 using a GIS-based EPIC model. Aldaya et al. (2010) estimated the WF of wheat and analyzed the green and blue water components for the major wheat-producing countries of the world. Siebert and Döll (2010) quantified the blue and green water consumption in global crop production as well as the potential production losses without irrigation using a grid-based approach for the period 1998-2002. Aldaya and Hoekstra (2010) assessed the water footprint of wheat in Italy, specifying for the first time the green, blue and gray water footprint. Mekonnen and Hoekstra $(2010,2011)$ conducted a global and high-resolution assessment of the green, blue and gray water footprint of wheat.

Meanwhile, many scholars have studied the water footprint of China's wheat production. Liu et al. (2007b) simulated the national blue and green water evapotranspiration of winter wheat using the GIS-based Environmental Policy Integrated Climate (GEPIC) model. Zhang (2009) and Sun et al. (2012) calculated the provincial water footprint of each kilogram of wheat product for the periods of 1997-2007 and the year 2009, respectively. Ge et al. (2010) estimated the water footprint of wheat in the North China Plain and distinguished between the green, blue and gray water footprints. Xu et al. (2013) studied the water footprint of wheat product in four basins using the life cycle assessment (LCA). Based on the evapotranspiration (ET) that was calculated with the CROPWAT model, Tian et al. (2013) analyzed the temporal variation of the water footprint of China's major food crops from 1978 to 2010. Including the loss of irrigation water (irrigation water that is not consumed by the field crop ET during the transmission and distribution processes of water sources to the field) in the blue water footprint calculation, Sun et al. (2013) assessed the water footprint of grain crops, including wheat, in typical irrigation districts of China using a modified method.

These studies have promoted the development of the water footprint theory. However, almost every study calculated the water consumption only at the field scale and under the assumption that the crop that was planted in farmland with irrigation suffered no water stress. The estimation methods of these studies did not consider the irrigation water loss through evaporation from the surface water during the water transport from source to cropland. Consequently, the results of these studies failed to reflect the actual water consumption in the irrigation system (Perry, 2014). In addition, few studies have contrasted the WF with traditional agricultural water utilisation assessment indicators.

In this study, we focused on the water footprint of wheat. The objective was to estimate the green and blue water footprint of wheat from a production perspective, distinguishing between crops that were cultivated in irrigated and rainfed farmland. Herein, we quantified the green and blue water footprint of wheat considering the actual water use by agricultural production at the regional scale. The water that evaporated from the water surface $(E)$ was included in the water footprint calculation, and the blue water footprint was obtained by the mutual check between the crop irrigation water requirement (IWR) and the actual irrigation water capacity (IWC). The effects of irrigation on the crop yield, water footprint and total water use in each province of China were also explored in this study.

\section{Data description}

The water footprints of wheat in irrigated and rainfed farmlands in China were calculated using a crop-model-coupledstatistics approach, where the required elements are consolidated, including the CROPWAT model, agricultural data in irrigated land and provincial agricultural data in total cropland. 


\subsection{FAO CROPWAT 8.0 model}

CROPWAT is a decision support tool that was developed by the Land and Water Development Division of UN Food and Agriculture Organization FAO (FAO, 2009). The computer program can be used to calculate the crop water requirements (CWR) and irrigation water requirements (IWR) based on the soil, climate and crop data. In addition, the program permits the development of irrigation schedules under different management conditions and the calculation of water supply schemes for various crop patterns (FAO, 2009). It is recommended by the Water Footprint Network to calculate the crop water footprint. All of the calculation procedures that were used in CROPWAT 8.0 are based on the two FAO publications of the Irrigation and Drainage Series: no. 56 "Crop evapotranspiration - Guidelines for computing crop water requirements" (Allen et al., 1998) and no. 33, "Yield response to water" (Doorenbos and Kassam, 1979).

\subsection{Agricultural data in irrigated land}

The statistical data, including the actual irrigation water capacity (IWC, the gross irrigation water diversion), the crop yield, the irrigation water utilisation coefficient $(\eta)$ and the irrigated area from the administration bureaus of 442 irrigation districts in 30 provinces (Fig. 1), were collected for this study. The actual $\eta$ was measured by engineers working for the administration bureau of the irrigation district.

\subsection{Agricultural data in the total cropland}

The climate data from 517 weather stations in 30 provinces of China were acquired from the China Meteorological Data Sharing Service System (CMA, 2011) and include the monthly average maximum temperature, the monthly average minimum temperature, the relative humidity, the wind speed, the sunshine hours and the precipitation. The provincial agricultural data, including the crop yield, crop-sowing area, agricultural acreage and irrigation area, were referenced from the China statistical yearbook 2011 (NBSC, 2011). The crop planting and harvesting dates of 180 agricultural observation stations were obtained from the Farmland Irrigation Research Institute, Chinese Academy of Agricultural Sciences (FIRI, CAAS). The crop coefficient $\left(K_{\mathrm{c}}\right)$ of wheat was referenced from Chen et al. (1995) and Duan et al. (2004). The $K_{\mathrm{c}}$ values that are listed in these references are the test results that were collected from irrigation experimental stations in different regions of China.

\section{Methods}

The blue and green water footprints of wheat were evaluated in this study. Both blue water and green water play a key role in crop growth in irrigated farmland, but in rainfed cropland, no blue water is consumed. The water footprints of

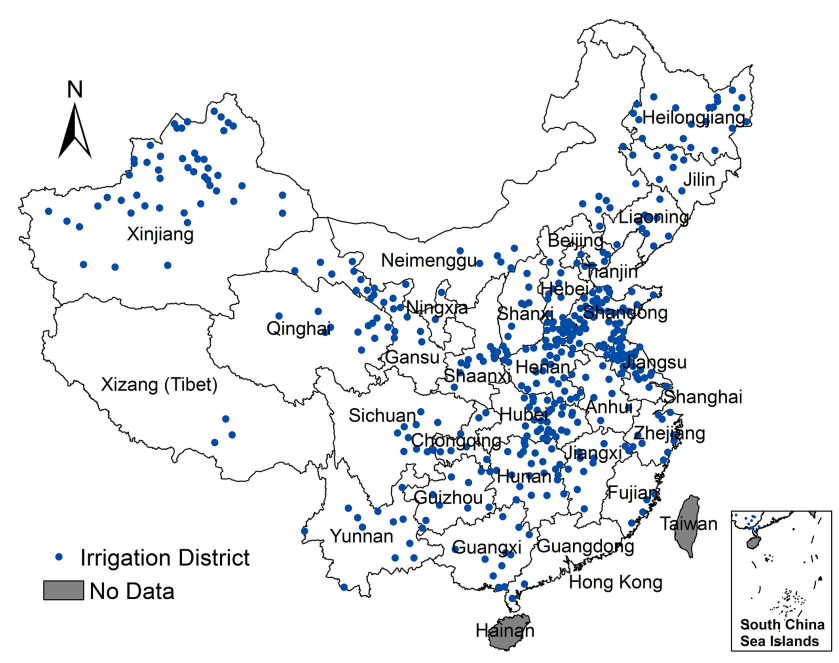

Figure 1. Distribution of 442 irrigation districts in 30 investigated provinces in China.

the per-kilogram wheat product in irrigated and rainfed croplands were estimated separately, after which each provincial total water footprint was calculated.

\subsection{Water footprint of the per-kilogram wheat product (WFP) in irrigated farmland}

Because the irrigated farmland within a province is scattered, the provincial WFP of the irrigated farmland should be the average of the water footprints from every piece of irrigated land. Therefore, 442 typical irrigation districts in 30 provinces (Hainan Province was excluded because it does not plant wheat) were used as the calculation units (see Fig. 1), and WFP for each irrigation district was calculated. Then, the WFP in the irrigated farmlands of each province was estimated using the weighted average method.

\subsubsection{Green water footprint (GWF)}

The GWF during the crop growth period is normally equal to the effective precipitation in both rainfed and irrigated cropland. The effective precipitation during the crop growth period can be calculated using Eq. (1), which is recommended by the FAO CROPWAT 8.0 Model.

$P_{\mathrm{e}}= \begin{cases}P \times(4.17-0.02 P), & P<83 \\ 4.17+0.1 P, & P .83,\end{cases}$

where $P$ and $P_{\mathrm{e}}$ are the 10-day precipitation and effective precipitation, respectively, in $\mathrm{mm}$.

To prevent $P_{\mathrm{e}}$ from exceeding the crop water requirement of wheat $\left(E T_{c}\right)$, the GWF was calculated as

$\mathrm{GWF}=A_{\mathrm{p}} \times \operatorname{Min}\left(\mathrm{ET}_{\mathrm{c}}, P_{\mathrm{e}}\right)$

and

$\mathrm{ET}_{\mathrm{c}}=K_{\mathrm{c}} \cdot \mathrm{ET}_{0}$ 
where $A_{\mathrm{p}}$ is the crop planting area in ha; $K_{\mathrm{c}}$ is the crop coefficient, which is dimensionless; and $\mathrm{ET}_{0}$ is the reference crop evapotranspiration as calculated by the CROPWAT 8.0 Model in mm.

\subsubsection{Blue water footprint (BWF)}

The blue water of wheat in an irrigation system is the sum of the irrigation water that evaporated from the water surface during the transmission and distribution the water sources to the field $\left(\mathrm{BWF}_{\mathrm{e}}\right)$ and the field evapotranspiration $\left(\mathrm{BWF}_{\mathrm{f}}\right)$ :

$\mathrm{BWF}=\mathrm{BWF}_{\mathrm{f}}+\mathrm{BWF}_{\mathrm{e}}$

The $\mathrm{BWF}_{\mathrm{f}}$ was obtained via the mutual check between the crop irrigation water requirement (IWR) as calculated by Eq. (5) and the irrigation water capacity (IWC) as surveyed by the administration bureaus of the studied irrigation districts.

$\mathrm{IWR}=\left\{\begin{array}{ll}0, & \mathrm{ET}_{\mathrm{c}} \leq P_{\mathrm{e}} \\ \mathrm{ET}_{\mathrm{c}}-P_{\mathrm{e}}, & \mathrm{ET}_{\mathrm{c}}>P_{\mathrm{e}}\end{array}\right.$.

The calculation process of $\mathrm{BWF}_{\mathrm{f}}$ in an irrigation district is as follows:

if $\eta \times$ IWC $>$ IWR, then

$\mathrm{BWF}_{\mathrm{f}}=\mathrm{WR}$

otherwise

$\mathrm{BWF}_{\mathrm{f}}=\eta \times \mathrm{IWC}$,

where $\eta$ is the irrigation water utilisation coefficient (irrigation efficiency), which is dimensionless.

The $\mathrm{BWF}_{\mathrm{e}}$ was estimated as follows:

$\mathrm{BWF}_{\mathrm{e}}=\alpha \times \mathrm{IWC}$

where $\alpha$ is the evaporation loss coefficient, which is dimensionless.

Referencing to the "Code for Design of Irrigation and Drainage Engineering" (MWR, 1999), the value of $\alpha$ could be (1) $A_{\mathrm{I}}<20 \times 10^{3}$ ha, $\alpha=3 \%$; (2) $20 \times 10^{3}$ ha $<A_{\mathrm{I}}<100 \times 10^{3} \mathrm{ha}, \alpha=5 \%$; or (3) $A_{\mathrm{I}}>$ $100 \times 10^{3}$ ha, $\alpha=8 \%$. $A_{\mathrm{I}}$ is the area of the irrigation district. The value of $\alpha$ that was recommended by the reference was calculated by irrigation engineering designers in China and is widely considered to agree with the actual conditions $(\mathrm{Li}$, 2006).

The water footprint of the per-kilogram wheat product in an irrigation district $\left(\mathrm{WFP}_{\mathrm{ID}}\right)$ was calculated as

$\mathrm{WFP}_{\mathrm{ID}}=\frac{\mathrm{GW}+\mathrm{BW}}{Y_{\mathrm{ID}}}=\mathrm{GWFP}_{\mathrm{ID}}+\mathrm{BWFP}_{\mathrm{ID}}$
$\mathrm{BWFP}_{\mathrm{ID}}=\mathrm{BWFP}_{\mathrm{ID}, \mathrm{ET}}+\mathrm{BWFP}_{\mathrm{ID}, \mathrm{CL}}$, where $Y_{\mathrm{ID}}$ is the crop yield of the irrigation district in ton/ha; GWFP ${ }_{I D}$ and BWFP ${ }_{\text {ID }}$ are the green and blue water footprints, respectively, of the per-kilogram wheat product in an irrigation district in $\mathrm{m}^{3} \mathrm{~kg}^{-1}$; and BWFPID,ET and $\mathrm{BWFP}_{\mathrm{ID}, \mathrm{CL}}$ are the blue water footprints of the per-kilogram wheat product for evapotranspiration and conveyance loss, respectively, in $\mathrm{m}^{3} \mathrm{~kg}^{-1}$.

\subsubsection{Water footprint of the per-kilogram wheat product in the irrigated farmland $\left(\mathrm{WFP}_{\mathrm{I}}\right)$ of each province}

The water footprint of per kg wheat product in irrigated farmland $\left(\mathrm{WFP}_{\mathrm{I}}\right)$ is estimated by the weighted average method:

$\mathrm{WFP}_{\mathrm{I}}=\frac{\sum\left(\mathrm{WFP}_{\mathrm{ID}}^{i} \times A^{i}\right)}{\sum A^{i}}$,

where $\mathrm{WFP}_{\mathrm{ID}}^{i}$ is the water footprint of the per-kilogram wheat product in the $i$ th irrigation district in $\mathrm{m}^{3} \mathrm{~kg}^{-1}$, and $A^{i}$ is the irrigation area of the $i$ th irrigation district in ha.

The green water footprint and the blue water footprint of the per-kilogram wheat product and the crop yield in irrigated farmland $\left(\mathrm{GWF}_{\mathrm{I}}, \mathrm{BWFP}\right.$, and $Y_{\mathrm{I}}$, respectively) can also be calculated using a method that is similar to Eq. (11).

\subsection{Water footprint of the per-kilogram wheat product in rainfed farmland $\left(\mathrm{WFP}_{\mathrm{R}}\right)$ of each province}

For the rainfed crops, the WF is derived from green water. The green water footprint (GWF) in the rainfed cropland of a province was calculated using Eqs. (1)-(5). Then, the water footprint of the per-kilogram wheat product in the rainfed farmland $\left(\mathrm{WFP}_{\mathrm{R}}\right)$ of a province was calculated as follows:

$\mathrm{WFP}_{\mathrm{R}}=\frac{\mathrm{GWF}}{Y_{\mathrm{R}}}$,

where $Y_{\mathrm{R}}$ is the crop yield in rainfed farmland in $\mathrm{tha}^{-1} \cdot Y_{\mathrm{R}}$ is hard to determine due to a lack of surveyed data from management institutions, thus different from the calculation of the crop yield of irrigated land in China. $Y_{\mathrm{R}}$ can be calculated using Eq. (13):

$Y_{\mathrm{R}}=\frac{O_{\mathrm{T}}-Y_{\mathrm{I}} \times A_{\mathrm{I}}}{A_{\mathrm{R}}}$

$A_{\mathrm{R}}=A-A_{\mathrm{I}}$,

where $O_{\mathrm{T}}$ is the provincial total output of the wheat product in $\mathrm{t} ; Y_{\mathrm{I}}$ is the crop yield in irrigated farmland in $\mathrm{tha}^{-1} ; A_{\mathrm{I}}$ is the area of irrigated farmland in ha; and $A_{\mathrm{R}}$ is the area of rainfed farmland in ha.

\subsection{Provincial water footprint of wheat in the total cropland}

The water footprint of wheat (WF) in the total cropland of a province is the sum of the water footprint in the irrigated land and that in the rainfed land: 
$\mathrm{WF}=\mathrm{WF}_{\mathrm{I}}+\mathrm{WF}_{\mathrm{R}}$

$\mathrm{WF}_{\mathrm{I}}=\mathrm{WFP}_{\mathrm{I}} \times Y_{\mathrm{I}} \times A_{\mathrm{I}}$

$\mathrm{WF}_{\mathrm{R}}=\mathrm{WFP}_{\mathrm{R}} \times Y_{\mathrm{R}} \times A_{\mathrm{R}}$,

where $\mathrm{WF}_{\mathrm{I}}$ and $\mathrm{WF}_{\mathrm{R}}$ are the water footprint of wheat in irrigated farmland and rainfed farmland, respectively, in $10^{6} \mathrm{~m}^{3}$; $Y_{\mathrm{I}}$ and $Y_{\mathrm{R}}$ are the crop yield in irrigated and rainfed farmland, respectively, in tha ${ }^{-1}$; and $A_{\mathrm{I}}$ and $A_{\mathrm{R}}$ are the sown area of irrigated and rainfed wheat in ha. The green water footprint (GWF) and blue water footprint (BWF) in the total cropland of a province can be calculated similarly to Eqs. (15)-(17). The provincial water footprint, green water footprint and blue water footprint of the per-kilogram wheat (WFP, GWFP and BWFP, respectively) in the total farmland can be calculated based on the WF, GWF and BWF.

\subsection{Total water use (TWU)}

The total water use (TWU) is a common and useful index when evaluating agricultural water utilisation, especially for irrigation agriculture. The TWU refers to the total amount of water that is invested in agricultural production in terms of evapotranspiration and percolation $\left(\mathrm{BW}_{\mathrm{p}}\right) . \mathrm{BW}_{\mathrm{p}}$, which can be calculated using Eq. (18), is the irrigation water that infiltrated into deep soil or groundwater mass that can neither be reused by crops during their growth stages nor sever the departments of the social economy.

$\mathrm{BW}_{\mathrm{p}}=\mathrm{IWC}-\mathrm{BWF}$

The blue water footprint (BWF) of a crop could not be satisfied if additional water withdrawal for percolation was not supplied by the reservoir or the headwork of an irrigation district. The regional $\mathrm{BW}_{\mathrm{p}}$ could be reduced by improving the quality of irrigation works. The TWU of wheat production in the cropland of China can also be estimated as follows:

$\mathrm{TWU}=\mathrm{WF}+\mathrm{BW}_{\mathrm{p}}$.

TWU, which reflects both the water productivity and irrigation efficiency, is the amount of water that is required to produce wheat at the regional scale. TWU is associated with the climate, crop variety, water diversion ability and condition of irrigation engineering. The WF is the most important part of TWU. The proportion of water use consumption in the TWU as a whole reflects the condition of agricultural water utilisation and the regional water conservation potential (Playan and Mateos, 2006; Cao et al., 2012, 2014). Therefore, it is meaningful to analyze the relationship between the WF and TWU for the areas facing water scarcity.

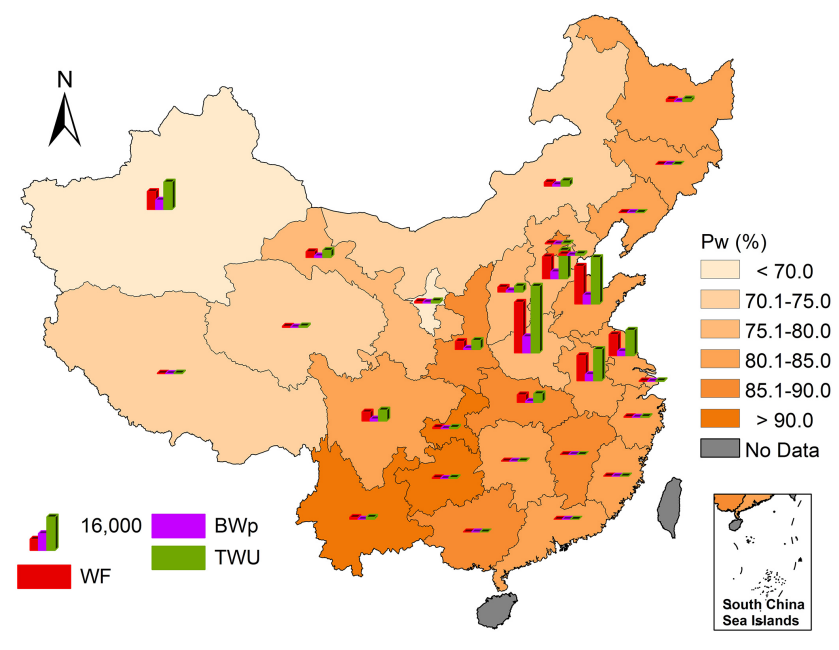

Figure 2. Provincial amount of water use for wheat production in China in 2010.

\section{Results and discussions}

\subsection{Water footprint (WF) and total water use (TWU)}

\subsubsection{From the total cropland perspective}

The national WF and TWU of wheat production are approximately 111548.2 and $142520.3 \mathrm{Mm}^{3}$, respectively. The data and the spatial distribution of the water use are shown in Table 1 and Fig. 2 for the 30 provinces in mainland China. The spatial difference of the water footprint was obvious among all of the provinces of China in 2010. The provinces with large WF values are concentrated in the Huang-Huai-Hai Plain, while those with low WF values mostly aggregate in south of the Yangtze River. Approximately $75.3 \%$ of the wheat product and $70.0 \%$ of the WF are contributed by the northern China sub-region in contrast to 0.85 and $1.05 \%$ by the northeastern. At the provincial level, large WFs are estimated for Henan $\left(25036.8 \mathrm{Mm}^{3}\right)$, Shandong $\left(18577.1 \mathrm{Mm}^{3}\right)$, Anhui $\left(12357.8 \mathrm{~m}^{3}\right)$, Hebei $\left(10731.8 \mathrm{Mm}^{3}\right)$, Jiangsu $\left(10419.5 \mathrm{Mm}^{3}\right)$ and Xinjiang $\left(8913.7 \mathrm{Mm}^{3}\right)$. These six provinces together contribute to $69.4 \%$ of the national total sown area, $80.0 \%$ of the wheat production, and $77.1 \%$ of the wheat productionrelated WF. The provinces with a WF of less than $50 \mathrm{Mm}^{3}$ include Guangdong $\left(3.2 \mathrm{Mm}^{3}\right)$, Gaungxi $\left(8.4 \mathrm{Mm}^{3}\right)$, Jilin $\left(15.4 \mathrm{Mm}^{3}\right)$, Fujian $\left(18.5 \mathrm{Mm}^{3}\right)$, Jiangxi $\left(27.1 \mathrm{Mm}^{3}\right)$ and Liaoning $\left(49.2 \mathrm{Mm}^{3}\right)$, whose combined WF constitutes only $0.1 \%$ of the national WF.

The national green water footprint (GWF) in wheat cultivation in 2010 was calculated to be $71629.7 \mathrm{Mm}^{3}$. The largest green water GWF was observed for Henan $\left(16511.4 \mathrm{Mm}^{3}\right)$, Shandong $\left(11499.6 \mathrm{Mm}^{3}\right)$, Anhui $\left(8489.1 \mathrm{Mm}^{3}\right)$, Jiangsu $\left(6883.0 \mathrm{Mm}^{3}\right)$ and Hebei $\left(6867.3 \mathrm{Mm}^{3}\right)$. These five provinces together account for $70.2 \%$ of the total blue water footprint related to wheat 
Table 1. Water use of wheat production for the 30 provinces of China in 2010.

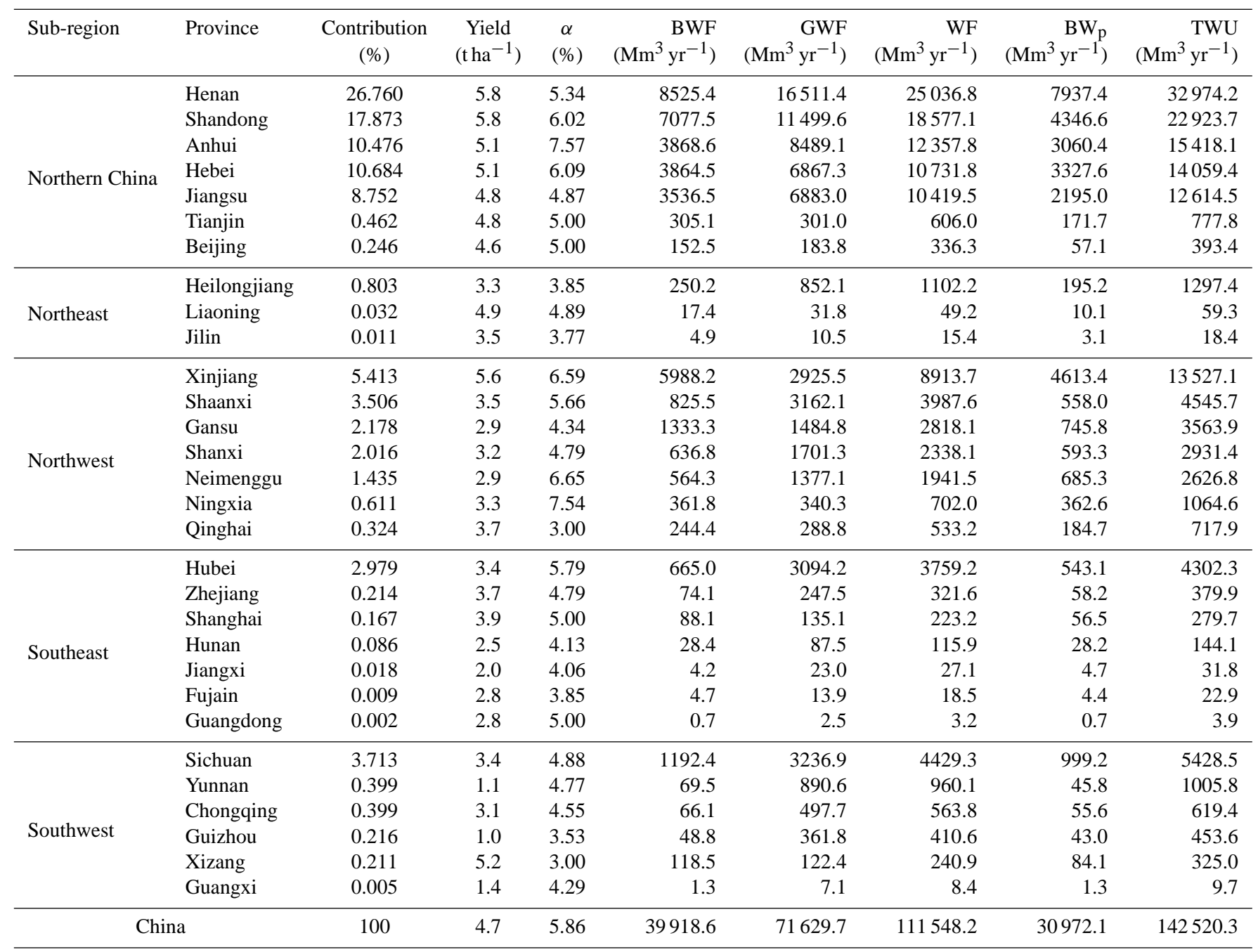

production. At the sub-regional level, the largest and smallest blue water footprints were in northern China $\left(50735.2 \mathrm{Mm}^{3}\right)$ and northeastern China $\left(894.4 \mathrm{Mm}^{3}\right)$, respectively. The blue water footprint (BWF) related to wheat production was $39918.6 \mathrm{Mm}^{3}$ in the studied year. The largest blue water footprint in wheat cultivation was also found in Henan $\left(8525.4 \mathrm{Mm}^{3}\right)$, Shandong $\left(7077.5 \mathrm{Mm}^{3}\right)$, Xinjiang $\left(5988.2 \mathrm{Mm}^{3}\right)$, Anhui $\left(3868.6 \mathrm{Mm}^{3}\right)$, Hebei $\left(3864.5 \mathrm{Mm}^{3}\right)$ and Jiangsu $\left(3536.5 \mathrm{Mm}^{3}\right)$. These six provinces alone account for approximately $82.3 \%$ of the national blue water footprint related to wheat production. The provinces with small green and blue water footprints in wheat production include Hunan, Liaoning, Jilin, Fujian, Jiangxi, Guangxi and Guangdong.

The estimated $\alpha$ in the irrigation system of China is approximately $5.86 \%$, and the provincial value ranges from approximately $3.00 \%$ in Xizang and Qinghai to $7.57 \%$ in Anhui (Table 1). China's blue water percolation $\left(\mathrm{BW}_{\mathrm{p}}\right)$ is $30972.1 \mathrm{Mm}^{3}$, accounting for approximately $43.7 \%$ of the total irrigation water $\left(70890.7 \mathrm{Mm}^{3}\right)$ that is invested in wheat production. Combining the $\mathrm{WF}$ and $\mathrm{BW}_{\mathrm{p}}$, the total water use (TWU) in the studied year was $142520.3 \mathrm{Mm}^{3}$. Similarly to the WF, large TWUs were found in Henan (32 974.2 $\mathrm{Mm}^{3}$ ), Shandong $\left(2923.7 \mathrm{Mm}^{3}\right)$, Anhui (15 418.1 $\mathrm{Mm}^{3}$ ), Hebei $\left(14059.4 \mathrm{Mm}^{3}\right)$, Xinjiang $\left(13527.1 \mathrm{Mm}^{3}\right)$ and Jiangsu $\left(10419.5 \mathrm{Mm}^{3}\right)$. These six provinces alone account for approximately $78.2 \%$ of the national TWU related to wheat production. The WF occupies the main part of TWU, and the national WF proportion in the TWU as a whole $\left(P_{\mathrm{w}}\right)$ is $78.3 \%$. The provinces with a high $P_{\mathrm{w}}$ are located in the southwest, while those with a low $P_{\mathrm{w}}$ are concentrated in northwestern China (Fig. 2).

\subsubsection{Distinguishing between irrigated and rainfed crops}

Irrigated farmland produced $80.4 \%$ of China's wheat in 2010. Table 2 presents the provincial and sub-regional 


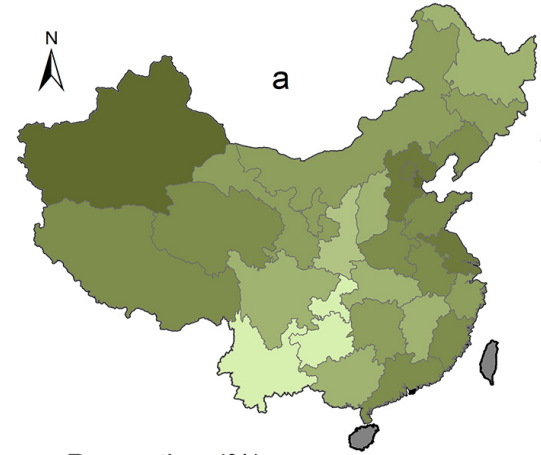

Porportion (\%)

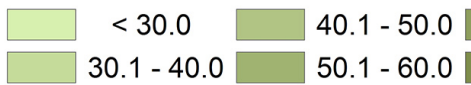

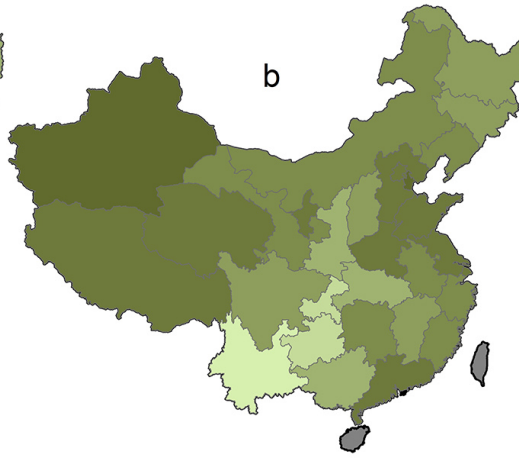

$60.1-70.0$

$70.1-80.0$
$80.1-90.0$

$>90.0$

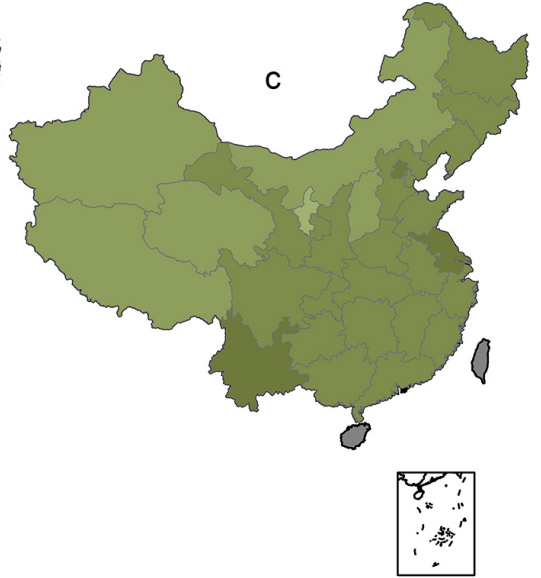

Figure 3. Proportions of water use in irrigated land in China, including (a) the proportion of the $\mathrm{WF}_{\mathrm{I}}$ in the WF, (b) the proportion of the TWU in the TWU and (c) the proportion of the WF in the TWU for irrigated crops $\left(\mathrm{WF}_{\mathrm{I}} / \mathrm{TWU}_{\mathrm{I}}\right)$.

wheat outputs, water footprint (WF) and total water use (TWU) in irrigated and rainfed farmland. Figure 3 illustrates the provincial WF-TWU relationship between the irrigated farmland and total cropland. The irrigated and rainfed WFs were 84365.1 and $27183.2 \mathrm{Mm}^{3}$, accounting for 75.6 and $24.4 \%$, respectively, of the national WF. Irrigated land produces $84.3,73.4,62.6,58.4$ and $53.7 \%$ wheat in northern, northwestern, southeastern, southwestern and northeastern China, contributing to $79.7,74.2,55.7,48.2$ and $62.5 \%$ of the WF, respectively.

The provinces with a large water footprint in irrigated land $\left(\mathrm{WF}_{\mathrm{I}}\right)$ include Henan $\left(19652.9 \mathrm{Mm}^{3}\right)$, Shandong $\left(14781.6 \mathrm{Mm}^{3}\right)$, Anhui $\left(9134.6 \mathrm{Mm}^{3}\right)$, Jiangsu $\left(8975.7 \mathrm{Mm}^{3}\right)$, Hebei $\left(8822.0 \mathrm{Mm}^{3}\right)$ and Xinjiang $\left(8586.7 \mathrm{Mm}^{3}\right)$. The sum of the $\mathrm{WF}_{\mathrm{I}}$ in these six provinces is up to $69953.5 \mathrm{Mm}^{3}$, accounting for $82.9 \%$ of the national WF of irrigated wheat. A large water footprint in the rainfed land $\left(\mathrm{WF}_{\mathrm{R}}\right)$ can be found in Henan $\left(5383.8 \mathrm{Mm}^{3}\right)$, Shandong $\left(3795.5 \mathrm{Mm}^{3}\right)$, Anhui $\left(3223.2 \mathrm{Mm}^{3}\right)$, Shaanxi $\left(2058.0 \mathrm{Mm}^{3}\right)$, Hebei $\left(1909.8 \mathrm{Mm}^{3}\right)$, Sichuan $\left(1830.7 \mathrm{Mm}^{3}\right)$ and Hubei $\left(1785.7 \mathrm{Mm}^{3}\right)$. These seven provinces together account for $73.5 \%$ of the total water footprint related to rainfed wheat. As illustrated in Fig. 3a, the proportions of the $\mathrm{WF}_{\mathrm{I}}\left(\right.$ or $\left.\mathrm{WF}_{\mathrm{R}}\right)$ in the water footprint of the total cropland are significantly different between provinces. In general, the proportion of the $\mathrm{WF}_{\mathrm{I}}$ in the WF in a province that has a large water footprint in the total cropland is high. The proportions of the $\mathrm{WF}_{\mathrm{I}}$ in the 6 provinces (including Henan, Shandong, Hebei, Beijing, Jiangsu, Tianjin and Xinjiang) exceed the national level, with the highest percentages of up to $96.3 \%$ in Xinjiang. In contrast, this proportion is no more than $30.0 \%$ in the Guizhou (29.6\%), Chongqing $(29.0 \%)$ and Yunnan $(19.3 \%)$ provinces.

The TWU is equal to the WF for rainfed crops; however, this is not the case for irrigated farmland. The TWU for irrigated wheat $\left(\mathrm{TWU}_{\mathrm{I}}\right)$ in 2010 was $115337.1 \mathrm{Mm}^{3}$, accounting for approximately $80.9 \%$ of the TWU. The distribution pattern of the provincial proportion of $\mathrm{TWU}_{\mathrm{I}}$ in the TWU as a whole in Fig. $3 b$ is quite similar to the proportion of the $\mathrm{WF}_{\mathrm{I}}$ in the WF as shown in Fig. 3a. The gap of percentage of the WF in the TWU for the irrigated crop (Fig. 3c) among provinces is very small. Most of the provinces (20) have values ranging from 70.0 to $80.0 \%$ in Fig. 3c.

\subsection{Blue and green water composition of the water footprint (WF) and total water use (TWU)}

From the perspective of the source of water resources, the provincial proportion of the green water footprint (GWF) in the WF in the total cropland and the composition of the TWU in the irrigated land are shown in Fig. 3. The spatial distribution pattern of the green water proportions in both the total cropland and the irrigated farmland (not shown in the figure) agrees with that of precipitation. The GWF proportions are low for the provinces in the North China Plain and northwestern China, while these proportions exceed $70.0 \%$ in most of the provinces south of the Yangtze River. The proportions of the green and blue water footprints for wheat production in the total cropland in 2010 were 64.2 and $35.8 \%$, respectively. The GWF proportion in Yunnan is $92.8 \%$, the highest among the 30 provinces along with the ratio of GWF to WF. The other regions with a GWF greater than $80.0 \%$ include Chongqing, Guizhou, Guangxi, Jiangxi and Hubei, at 88.3, $88.1,84.9,84.6$, and $82.3 \%$, respectively. The GWF proportions of Gansu, Tianjin, Xizang (Tibet), Ningxia and Xinjiang rank the lowest in China; the proportion in Xinjiang is only $32.8 \%$.

The national proportions of the green water footprint (GWF), blue water footprint (BWF) and blue water percolation $\left(\mathrm{BW}_{\mathrm{p}}\right)$ in the TWU for the irrigated land were 38.5, 34.6 and $26.9 \%$, respectively. As revealed in Fig. 4, the GWF proportions in most (21) of the provinces were 
Table 2. Provincial water footprint of wheat production in irrigated and rainfed farmland.

\begin{tabular}{|c|c|c|c|c|c|c|c|c|}
\hline \multirow{2}{*}{ Sub-region } & \multirow{2}{*}{ Province } & \multicolumn{5}{|c|}{ Irrigated } & \multicolumn{2}{|c|}{ Rainfed } \\
\hline & & $\begin{array}{l}\text { Output } \\
\left(10^{3} t\right)\end{array}$ & $\begin{array}{r}\mathrm{BWF} \\
\left(\mathrm{Mm}^{3} \mathrm{yr}^{-1}\right)\end{array}$ & $\begin{array}{r}\mathrm{BWF}_{\mathrm{f}} \\
\left(\mathrm{Mm}^{3} \mathrm{yr}^{-1}\right)\end{array}$ & $\begin{array}{r}\mathrm{GWF}_{\mathrm{I}} \\
\left(\mathrm{Mm}^{3} \mathrm{yr}^{-1}\right)\end{array}$ & $\begin{array}{r}\mathrm{WF}_{\mathrm{I}} \\
\left(\mathrm{Mm}^{3} \mathrm{yr}^{-1}\right)\end{array}$ & $\begin{array}{l}\text { Output } \\
\left(10^{3} t\right)\end{array}$ & $\begin{array}{r}\mathrm{WF}_{\mathrm{R}} \\
\left(\mathrm{Mm}^{3} \mathrm{yr}^{-1}\right)\end{array}$ \\
\hline \multirow{7}{*}{ Northern China } & Henan & 2590.8 & 878.4 & 7647.0 & 11127.5 & 19652.9 & 491.5 & 5383.8 \\
\hline & Shandong & 1725.6 & 688.2 & 6389.3 & 7704.1 & 14781.6 & 333.0 & 3795.5 \\
\hline & Anhui & 965.2 & 524.4 & 3344.2 & 5266.0 & 9134.6 & 241.5 & 3223.2 \\
\hline & Hebei & 1077.9 & 437.9 & 3426.6 & 4957.5 & 8822.0 & 152.8 & 1909.8 \\
\hline & Jiangsu & 873.4 & 279.1 & 3257.4 & 5439.2 & 8975.7 & 134.7 & 1443.8 \\
\hline & Tianjin & 49.7 & 23.8 & 281.2 & 256.3 & 561.4 & 3.5 & 44.6 \\
\hline & Beijing & 24.3 & 10.5 & 142.0 & 132.8 & 285.3 & 4.1 & 51.0 \\
\hline \multirow{3}{*}{ Northeast } & Heilongjiang & 49.0 & 17.2 & 233.0 & 334.2 & 584.4 & 43.5 & 517.8 \\
\hline & Liaoning & 2.6 & 1.3 & 16.0 & 17.9 & 35.3 & 1.1 & 13.9 \\
\hline & Jilin & 0.7 & 0.3 & 4.6 & 4.7 & 9.6 & 0.5 & 5.8 \\
\hline \multirow{7}{*}{ Northwest } & Xinjiang & 605.3 & 698.9 & 5289.3 & 2598.5 & 8586.7 & 18.1 & 327.0 \\
\hline & Shaanxi & 217.0 & 78.3 & 747.3 & 1104.1 & 1929.6 & 186.8 & 2058.0 \\
\hline & Gansu & 150.0 & 90.2 & 1243.1 & 515.5 & 1848.9 & 100.9 & 969.2 \\
\hline & Shanxi & 156.8 & 58.9 & 577.9 & 682.6 & 1319.4 & 75.5 & 1018.8 \\
\hline & Neimenggu & 108.7 & 83.1 & 481.3 & 637.4 & 1201.8 & 56.6 & 739.7 \\
\hline & Ningxia & 50.3 & 54.6 & 307.2 & 127.8 & 489.6 & 20.0 & 212.5 \\
\hline & Qinghai & 27.1 & 12.9 & 231.5 & 153.9 & 398.2 & 10.1 & 134.9 \\
\hline \multirow{7}{*}{ Southeast } & Hubei & 202.3 & 70.0 & 595.0 & 1308.5 & 1973.5 & 140.8 & 1785.7 \\
\hline & Zhejiang & 20.3 & 6.3 & 67.8 & 150.7 & 224.8 & 4.4 & 96.8 \\
\hline & Shanghai & 17.5 & 7.2 & 80.9 & 99.8 & 187.9 & 1.7 & 35.3 \\
\hline & Hunan & 8.0 & 2.3 & 26.1 & 46.4 & 74.8 & 1.9 & 41.1 \\
\hline & Jiangxi & 1.5 & 0.4 & 3.8 & 10.9 & 15.0 & 0.6 & 12.1 \\
\hline & Fujain & 0.8 & 0.3 & 4.3 & 8.5 & 13.1 & 0.2 & 5.4 \\
\hline & Guangdong & 0.2 & 0.1 & 0.7 & 1.8 & 2.5 & 0.1 & 0.8 \\
\hline \multirow{6}{*}{ Southwest } & Sichuan & 269.1 & 107.0 & 1085.4 & 1406.1 & 2598.5 & 158.6 & 1830.7 \\
\hline & Yunnan & 16.5 & 5.5 & 64.0 & 116.2 & 185.7 & 29.5 & 774.4 \\
\hline & Chongqing & 17.0 & 5.5 & 60.6 & 97.4 & 163.5 & 28.9 & 400.3 \\
\hline & Guizhou & 10.3 & 3.2 & 45.6 & 72.8 & 121.6 & 14.5 & 289.0 \\
\hline & Xizang & 19.0 & 6.1 & 112.4 & 64.0 & 182.5 & 5.3 & 58.4 \\
\hline & Guangxi & 0.3 & 0.1 & 1.2 & 3.2 & 4.5 & 0.2 & 3.9 \\
\hline \multicolumn{2}{|c|}{ China } & 9257.3 & 4152.1 & 35766.5 & 44446.5 & 84365.1 & 2260.8 & 27183.2 \\
\hline
\end{tabular}

greater than the national average and exceed $50.0 \%$ in 6 provinces, namely Yunnan $(50.2 \%)$, Hubei $(52.0 \%)$, Zhejiang $(53.2 \%)$, Jiangxi $(55.0 \%)$, Guangdong $(55.6 \%)$ and Guangxi $(55.7 \%)$. In contrast, provinces with low GWF proportions for irrigated wheat include Gansu (19.9\%), Xinjiang $(19.7 \%)$ and Ningxia $(15.0 \%)$, none of which was greater than $20.0 \%$. The irrigation water utilisation coefficient $(\eta)$ was 0.503 in the irrigation system of China in the studied year, and the provincial values ranged from 0.424 (in Ningxia) to 0.678 (in Beijing). Several provinces that are characterised by a WF that contains a large share of $\mathrm{BW}_{\mathrm{p}}$ in irrigated land include Ningxia (42.5\%), Neimenggu $(36.3 \%)$ and Xinjiang $(34.9 \%)$. The $\mathrm{BWF}_{\mathrm{CL}}$ proportions of 21 provinces were between 20.0 and $30.0 \%$. With the highest irrigation efficiency, Beijing has a water-wasting proportion for irrigated wheat that is lower than that of all of the studied provinces, at only $16.7 \%$.

\subsection{Water footprint per kilogram of wheat (WFP)}

\subsubsection{WFP in the total cropland}

The national average WFP in 2010 was $0.968 \mathrm{~m}^{3} \mathrm{~kg}^{-1}$. The results (in Fig. 5) demonstrate a great variation among provinces. The provinces in and around the Huang-HuaiHai Plain are lower in WFP, while the provinces south of the Yangtze River and northwestern China have a lower wateruse efficiency. Only three provinces have WFPs below the national average, namely Shandong $\left(0.902 \mathrm{~m}^{3} \mathrm{~kg}^{-1}\right)$, Hebei $\left(0.872 \mathrm{~m}^{3} \mathrm{~kg}^{-1}\right)$ and Henan $\left(0.812 \mathrm{~m}^{3} \mathrm{~kg}^{-1}\right)$. These four provinces together produce $63.7 \mathrm{Mt}$ of wheat, accumulatively 
Table 3. Documented results for the WFP of wheat production in China.

\begin{tabular}{lllccc}
\hline Reference & Year/period & $\begin{array}{l}\text { WFP } \\
\left(\mathrm{m}^{3} \mathrm{~kg}^{-1}\right)\end{array}$ & $\begin{array}{c}\text { Crop yield } \\
\left(\mathrm{tha}^{-1}\right)\end{array}$ & $\begin{array}{c}\text { Field ET } \\
(\mathrm{mm})\end{array}$ & $\begin{array}{c}\text { Proportion of } \\
\text { green water }\end{array}$ \\
\hline & & 0.968 & & - & $64.2 \%$ \\
This study & 2010 & $\begin{array}{l}1.007^{*} \\
0.932(\mathrm{ETP})\end{array}$ & 4.7 & - & - \\
& & $0.971(\mathrm{ETP})$ & & 463 & $66.7 \%$ \\
Sun et al. (2012) & 2009 & 1.071 & 4.7 & 508 & $64.1 \%$ \\
Liu et al. (2007a) & 2000 & 1.266 & 3.7 & 473 & - \\
Liu et al. (2007c) & $1999-2001$ & 0.975 & 4.1 & 430 & - \\
Zhang (2009) & $1997-2007$ & 1.190 & 4.1 & 484 & - \\
Mekonnen and Hoekstra (2010) & $1996-2005$ & 1.286 & 3.9 & 505 & $63.8 \%$ \\
Hoekstra and Hung (2005) & $1995-1999$ & 0.690 & 3.8 & 262 & - \\
\hline
\end{tabular}

* assumed a sufficient irrigation.

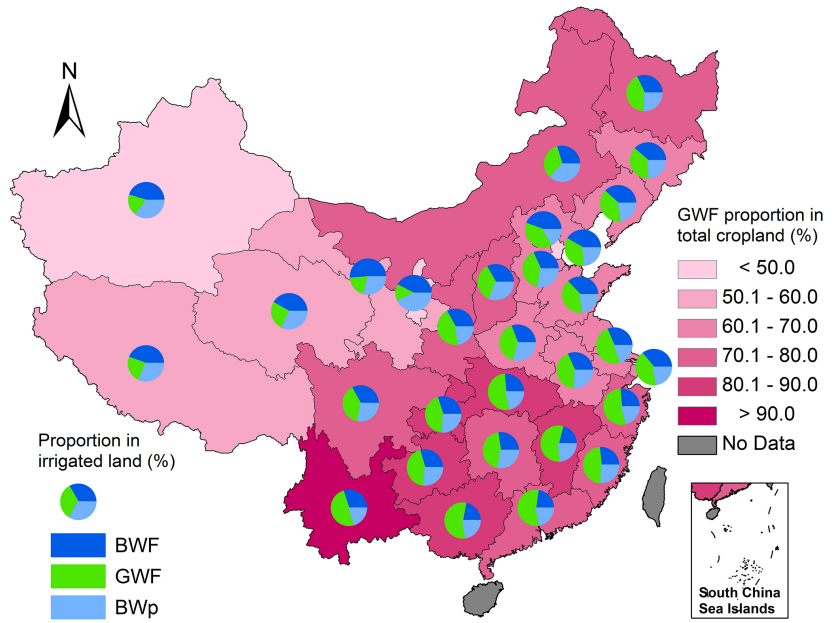

Figure 4. Proportion of GWF (green water footprint) in the total cropland and the composition of the TWU (total water use) in the irrigated land in China.

contributing to $55.3 \%$ of the total output of China. Thus, increasing harvest from the regions with low WFP improves the water productivity (WP) of the country. In contrast, some provinces, such as Fujian, Yunnan and Xinjiang, have a WFP greater than $1500 \mathrm{~m}^{3} \mathrm{~kg}^{-1}$. Xinjiang was the sixth largest wheat producer of China in 2010 and was one of the most promising and pressing regions reducing the water footprint.

Apart from the WFP variation, the spatial distribution of the green water footprint per kilogram of wheat (GWFP) and the blue water footprint per kilogram of wheat (BWFP) is also displayed in Fig. 5. The distribution patterns of the GWFP and BWFP are opposite. In the sunny, hot and resource-adequate northwestern provinces, wheat is planted extensively in some areas despite the poor precipitation. However, a large amount of irrigation water diversion is required for crop growth in these areas. Some provinces in the southwest (including Yunnan, Guizhou and
Chongqing), with an average annual precipitation of greater than $1500 \mathrm{~mm}$, require almost no irrigation for wheat production. The climatic conditions in southeastern provinces, such as Hunan, Fujian and Guangdong, are similar to those of southwestern provinces. This mismatch of rainy seasons, the growth period of wheat and the low yield lead to a relatively low GWFP and a high BWFP. The North China Plain is the winter-wheat-intensive centre of the country. Precipitation during the growth period of wheat in North China is approximately $300 \mathrm{~mm}$; therefore, a substantial amount of irrigation water is demanded, making the BWFP greater than that of the southern provinces. The crop yield in the provinces in the plain is greater than that of any other region, resulting mainly in low WFPs in these provinces.

The calculated national WFP value in this study was compared to that reported in the literature (Table 3). Because the WFP in previous studies was calculated at the field scale assuming sufficient irrigation, the water footprint (WF) and consumptive water use (ET) per kilogram of wheat under actual irrigation and sufficient irrigation are listed in the table. Hoekstra and Hung (2005) obtained a WFP of approximately $0.690 \mathrm{~m}^{3} \mathrm{~kg}^{-1}$, which is much lower than that in any other study. The WFP of wheat from 1995 to 1999 should be higher because of the low actual crop yield. The WFP in this report was $0.968 \mathrm{~m}^{3} \mathrm{~kg}^{-1}$, which is lower than $1.266 \mathrm{~m}^{3} \mathrm{~kg}^{-1}$ in Liu et al. (2007a), $1.190 \mathrm{~m}^{3} \mathrm{~kg}^{-1}$ in Zhang (2009) and $1.286 \mathrm{~m}^{3} \mathrm{~kg}^{-1}$ in Mekonnen and Hoekstra (2010) and approximately the same as the water footprint of the wheat product as estimated by Sun et al. (2013) and Liu et al. $(2007 \mathrm{c})$.

The national crop yield and field evapotranspiration (ET) for each study are also enumerated in Table 3 for a clear comparison. The national wheat crop yield increased over time in the last two decades and reached up to $4.7 \mathrm{tha}^{-1}$ in 2010. The national crop water requirement (ET under sufficient irrigation) of wheat ranged from 430 to $510 \mathrm{~mm}$ except for the value of $262 \mathrm{~mm}$ in Hoekstra and Hung (2005). 

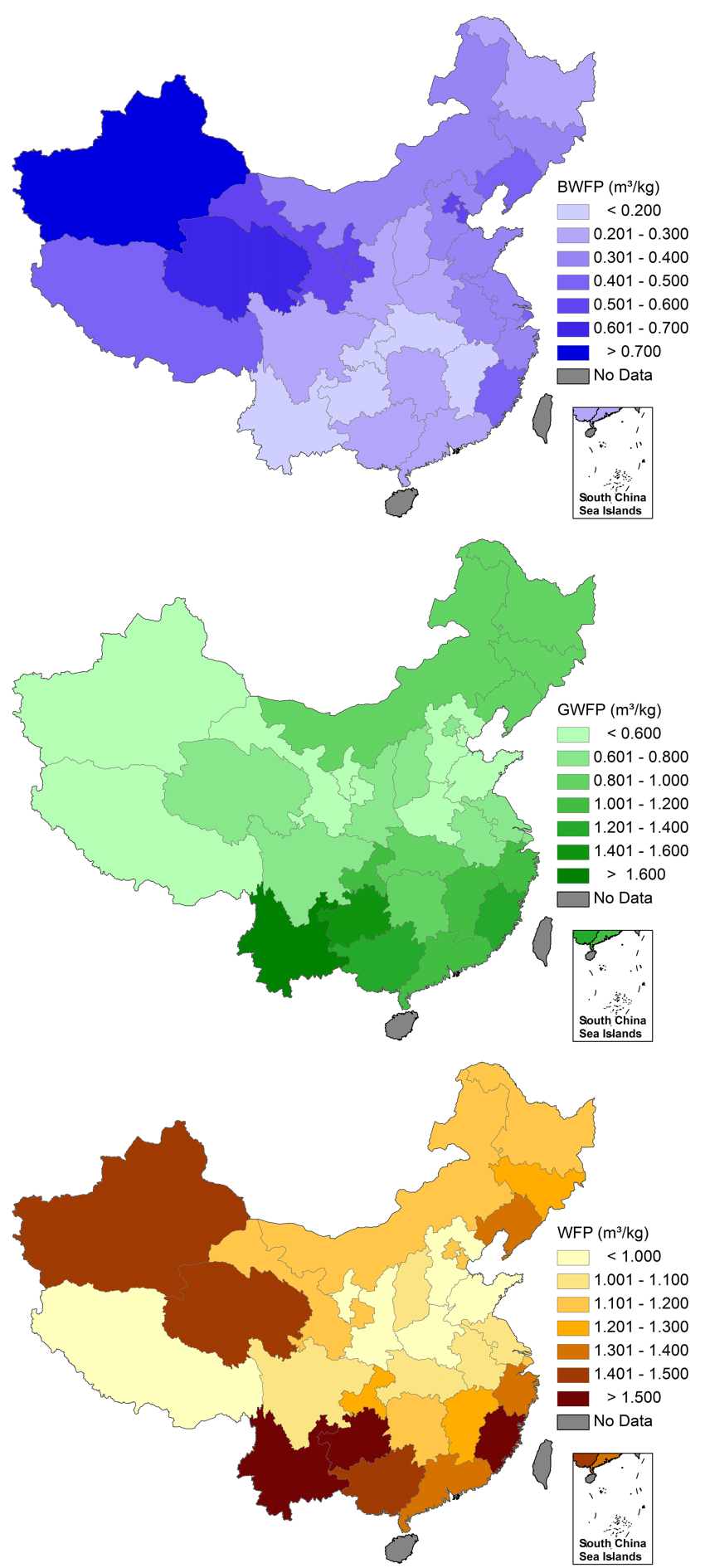

Figure 5. The blue, green and total water footprints per kilogram of wheat product in China.

The variation in the calculated ET from year to year is normal due to the different climatic conditions. The crop water requirement and actual ET of this study were approximately 461 and $443 \mathrm{~mm}$, respectively, and are very close to those Liu et al. (2007a), Liu et al. (2007c) and Zhang (2009).
Distinguishing between crops that were cultivated in irrigated and rainfed farmlands, Liu et al. (2007a) estimated the ET using the grid-based GEPIC model. Liu et al. (2007c) referenced a crop water requirement that was averaged for many years from Chen et al. (1995), and Zhang (2009) referenced a crop water requirement that was averaged for many years from Liao (2005). In addition, the crop yield $4.1 \mathrm{tha}^{-1}$ in Liu et al. (2007c) is the average of the Henan, Shandong, Hebei, Anhui and Jiangsu Provinces instead of the national average. Sun et al. (2012) and Mekonnen and Hoekstra (2010) obtained an ET of greater than $500 \mathrm{~mm}$ using a different approach. Similar to our study, Sun et al. (2012) also applied the CROPWAT model and climate data from the China Meteorological Data Sharing Service System (CMA) but did not distinguish between irrigated and rainfed crops. Among these previous studies, only three studies distinguished between the green and blue water footprints. The proportions of green water at the field scale in both this paper and Mekonnen and Hoekstra (2010) were approximately $65.0 \%$. Our green water proportion in the field ET, under both sufficient and actual irrigation conditions, was greater than 51.0 and $63.8 \%$, the values from Sun et al. (2013) and Mekonnen and Hoekstra (2010), respectively. It is necessary to note that the crops that were cultivated under land-equipped irrigation may not be irrigated crops. Many reasons, such as not enough water in the source and deficient irrigation facilities, may cause an insufficiency in irrigation. The gap between the actual and potential ET without water stress was approximately $18 \mathrm{~mm}$, accounting for approximately $3.9 \%$ of the crop water requirement. The $18 \mathrm{~mm}$ could equate to $4474 \mathrm{Mm}^{3}$ of consumed water use on the field scale. The national average irrigation efficiency in the study year was approximately 0.503 , indicating that China's irrigation water deficit in 2010 was approximately $890 \mathrm{Mm}^{3}$. In addition, the percolation loss of irrigation water during transmission and distribution was approximately $30972 \mathrm{Mm}^{3}$, which is 3.5 times the irrigation water deficit. The irrigation water requirement could be met if the efficiency of the irrigation system of China was enhanced by $13.0 \%$ (to 0.566 ). Increasing the irrigation efficiency is of great importance for the utilisation of water resources.

A significant difference between our report and the previous studies is the irrigation water sources. Based on the actual irrigation from typical irrigation districts, we estimated the gap between the crop water requirement and actual field evapotranspiration. However, because the actual agricultural data in irrigated land are affected by human factors (artificially influenced), we estimate water use in crop production based on finite sample points. Therefore, the agricultural production data and weather data cannot be processed by gridding or spatial interpolation but by weighted averaging. Our estimates of the water consumption and water footprint of wheat production are better than the previous estimates of Hoekstra and Hung (2005), Zhang (2009) and Sun et al. (2012). However, these estimates are more accurate than 
Table 4. Crop yield and total water use of per $\mathrm{kg}$ wheat product for three categories.

\begin{tabular}{|c|c|c|c|c|c|c|c|c|}
\hline \multirow{2}{*}{ Category } & \multicolumn{3}{|c|}{ Crop yield $\left(\mathrm{t} \mathrm{ha}^{-1}\right)$} & \multirow{2}{*}{ QY } & \multicolumn{3}{|c|}{ Total water use of per kg product $\left(\mathrm{m}^{3} \mathrm{~kg}^{-1}\right)$} & \multirow{2}{*}{ QU } \\
\hline & $\begin{array}{l}\text { Total cropland } \\
\qquad(Y)\end{array}$ & $\begin{array}{l}\text { Irrigated } \\
\qquad\left(Y_{\mathrm{I}}\right)\end{array}$ & $\begin{array}{c}\text { Rainfed } \\
\left(Y_{\mathrm{R}}\right)\end{array}$ & & $\begin{array}{l}\text { Total cropland } \\
\text { (TWUP) }\end{array}$ & $\begin{array}{l}\text { Irrigated } \\
\left(\mathrm{TWUP}_{\mathrm{I}}\right)\end{array}$ & $\begin{array}{l}\text { Rainfed } \\
\left(\text { TWUP }_{R}\right)\end{array}$ & \\
\hline Category I & 2.4 & 2.8 & 1.7 & 1.64 & 1.762 & 1.492 & 2.099 & 0.71 \\
\hline Category II & 4.9 & 6.8 & 2.4 & 2.83 & 1.165 & 1.155 & 1.208 & 0.96 \\
\hline Category III & 4.1 & 5.4 & 2.1 & 2.57 & 1.522 & 1.618 & 1.140 & 1.42 \\
\hline China & 4.7 & 6.4 & 2.3 & 2.76 & 1.237 & 1.246 & 1.202 & 1.04 \\
\hline
\end{tabular}

are the results from the grid-based estimates as presented by Liu et al. (2007a) and Mekonnen and Hoekstra (2010, 2011).

\subsubsection{Comparison between the rainfed and irrigated WFPs and TWUPs}

The calculated national average water footprint per kilogram of rainfed wheat $\left(\mathrm{WFP}_{\mathrm{R}}\right)$ was $1.202 \mathrm{~m}^{3} \mathrm{~kg}^{-1}$. The results (in Fig. 6) demonstrate a great variation among the 30 provinces. The highest $\mathrm{WFP}_{\mathrm{R}}$ was found for Zhejiang, Fujian and Yunnan, with $\mathrm{WFP}_{\mathrm{R}}$ values of 2.210, 2.374 and $2.623 \mathrm{~m}^{3} \mathrm{~kg}^{-1}$, respectively. In contrast, some provinces, such as Gansu, Ningxia, Jiangsu and Henan, have wheat water footprint values of approximately 0.900 $1.100 \mathrm{~m}^{3} \mathrm{~kg}^{-1}$ in rainfed farmland. The national average water footprint per kilogram of wheat in irrigated land $\left(\mathrm{WFP}_{\mathrm{I}}\right)$ was $0.911 \mathrm{~m}^{3} \mathrm{~kg}^{-1}$, slightly lower than the $\mathrm{WFP}_{\mathrm{R}}$. The WFP I in Fujian was $1.658 \mathrm{~m}^{3} \mathrm{~kg}^{-1}$, ranking the highest among all of the provinces. The WFP I of Qinghai and Xinjiang also surpassed $1.400 \mathrm{~m}^{3} \mathrm{~kg}^{-1}$. The $\mathrm{WFP}_{\mathrm{I}}$ in the other 22 provinces were greater than the national average. The lowest WFPI was found in Henan $\left(0.759 \mathrm{~m}^{3} \mathrm{~kg}^{-1}\right)$, Hebei $\left(0.818 \mathrm{~m}^{3} \mathrm{~kg}^{-1}\right)$, Shanxi $\left(0.842 \mathrm{~m}^{3} \mathrm{~kg}^{-1}\right)$, Shandong $\left(0.857 \mathrm{~m}^{3} \mathrm{~kg}^{-1}\right)$, and Shaanxi $\left(0.889 \mathrm{~m}^{3} \mathrm{~kg}^{-1}\right)$, all of which are major wheat-producing areas of China. The total water use per kilogram of wheat in the rainfed land $\left(\mathrm{TWUP}_{\mathrm{R}}\right)$ was equal to the $W_{F P}$. The total water use per kilogram of irrigated wheat $\left(\right.$ TWUP $\left._{\mathrm{I}}\right)$ in China was approximately $1.237 \mathrm{~m}^{3} \mathrm{~kg}^{-1}$, and the provincial value ranges from $1.065 \mathrm{~m}^{3} \mathrm{~kg}^{-1}$ in Henan to $2.214 \mathrm{~m}^{3} \mathrm{~kg}^{-1}$ in Fujian.

The crop yield when rainfed will be enhanced under irrigation, which is the case for water-deficient areas. The calculated result based on statistical data indicates that the crop yield in irrigated land is 2.76 times greater than that of rainfed wheat. However, irrigation does not always achieve both the water-conserving and production-increasing goals. As illustrated in Fig. 6, TWUP ${ }_{I}$ and $W P_{I}$ are not equal to those in rainfed land. The TWUP ${ }_{I}$ is greater than the $W_{F P}$ in most provinces in northern China, while the opposite trend occurs in the south. To compare the crop yield and water footprint per kilogram of wheat between irrigated and rainfed farmlands, the four indexes QW, QF, QU and QY are defined as follows:

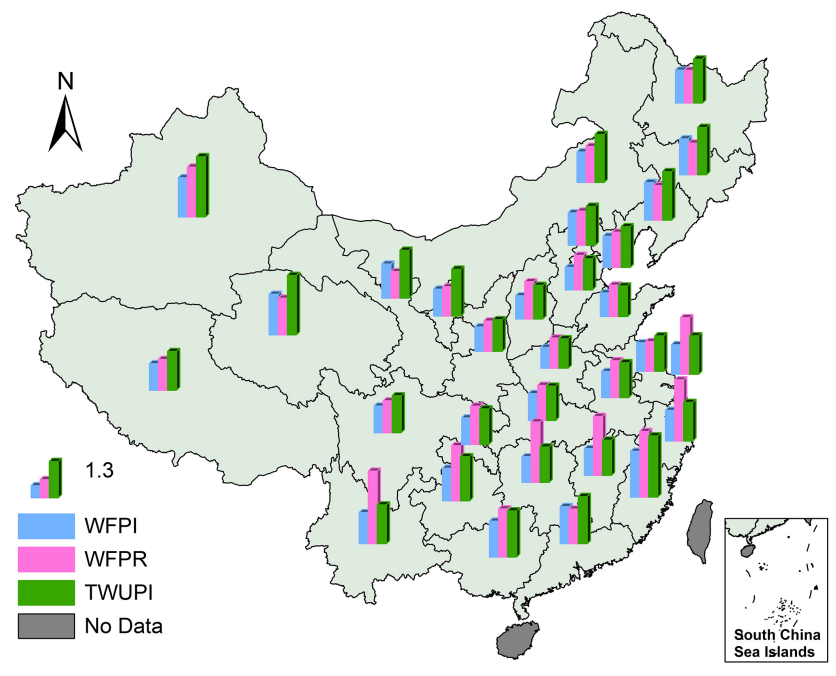

Figure 6. Water footprint and total water use per kilogram of wheat product in irrigated and rainfed lands in China.

$\mathrm{QW}=\mathrm{ETP}_{\mathrm{I}} / \mathrm{ETP}_{\mathrm{R}}$

$\mathrm{QF}=\mathrm{WFP}_{\mathrm{I}} / \mathrm{WFP}_{\mathrm{R}}$

$\mathrm{QU}=\mathrm{TWUP}_{\mathrm{I}} / \mathrm{TWUP}_{\mathrm{R}}$

$\mathrm{QY}=Y_{\mathrm{I}} / Y_{\mathrm{R}}$,

where $\mathrm{ETP}_{\mathrm{I}}$ and $\mathrm{ETP}_{\mathrm{R}}$ are the field evapotranspiration (ET) for the per-kilogram wheat product in irrigated and rainfed lands, respectively; and $\mathrm{ETP}_{\mathrm{R}}=\mathrm{WFP}_{\mathrm{R}}$. The other parameters in Eqs. (20)-(23) are defined in Sect. 3 and above. The calculated provincial results of QW, QF, QU and QY in 2010 are shown in Fig. 7. The national QW, QF, QU and QY are 0.72, 0.76, 1.04 and 2.76, indicating that the crop yield, field water productivity $\left(\mathrm{WP}_{\mathrm{f}}\right)$, and total water use can be increased by 176,39 and $4 \%$, while the water footprint (WF) can be decreased by approximately $28.0 \%$ when wheat is irrigated. Irrigation helps achieve the dual benefit of yield increase and water conservation at the field scale in almost all of the provinces of China. Nevertheless, the estimated results from the water footprint perspective and based on the regional scale indicate that an extra $0.044 \mathrm{~m}^{3}$ of water resources are required for irrigated 


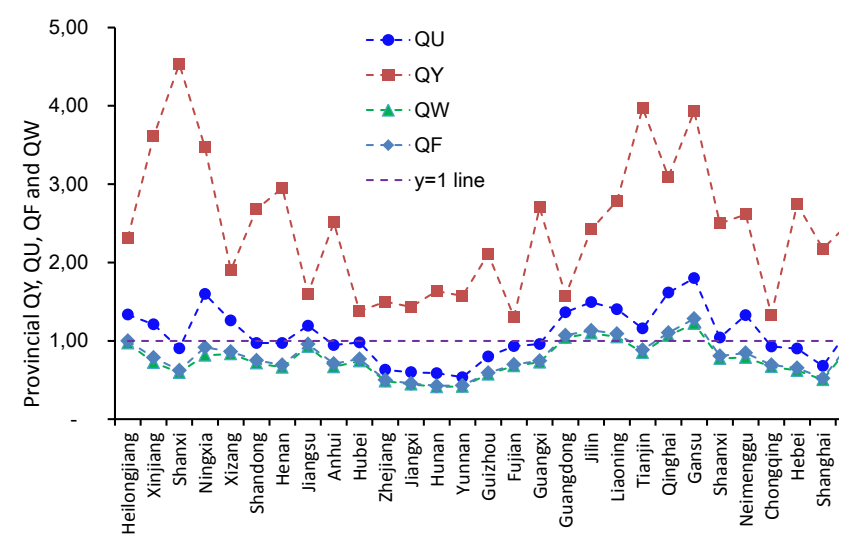

Figure 7. Provincial value of QU, QW, QY and QF in 2010.

land compared to the water amount in rainfed land to produce $1 \mathrm{~kg}$ of wheat product. Irrigation increases the crop yield and reduces the water footprint per kilogram of product while increasing the total water use of China's wheat production. The QW and $\mathrm{QF}$ in most of the 30 studied provinces are lower than 1 , which is not the case for QW. The provinces can be divided into three categories according to QU value: (I) $\mathrm{QU}<0.900$; (II) $0.900<\mathrm{QU}<1.100$ and (III) QU $>1.100$. The provinces with low QU values, including Yunnan, Hunan, Jiangxi, Zhejiang, Shanghai and Guizhou, belong to Category I; with QU values approximately 1.000, the 10 provinces Hebei, Shanxi, Chongqing, Fujian, Anhui, Guangxi, Henan Shandong, Hubei, and Shaanxi belong to Category II; and the remaining 14 provinces fall into Category III. The QW and QF in the three categories are below 1.00, while the $\mathrm{QU}$ in reaches up to 1.42 in Category III.

The contributions to the country of the three categories for wheat output, sown area, WF, TWU and IWC are shown in Fig. 7. In addition, the crop yield and TWU of the perkilogram wheat product for the three categories as well as the QU and QY (including the values in the total cropland, irrigated land and rainfed land) are listed in Table 4.

The total water use per kilogram of product in the irrigated $\left(\mathrm{TWUP}_{\mathrm{I}}\right)$ and rainfed $\left(\mathrm{TWUP}_{\mathrm{R}}, \mathrm{WFP}_{\mathrm{R}}\right)$ farmlands of Category I is 1.492 and $2.099 \mathrm{~m}^{3} \mathrm{~kg}^{-1}$, respectively, and the value of QU is 0.71 . Irrigation conserves water resources by $29 \%$ while increasing the crop yield by $64 \%$ in this category. Water-conserving and production-increasing targets can be achieved simultaneously through irrigation in these provinces. Category I provinces should expand the wheat acreage and irrigation area as far as the water-use efficiency is concerned. However, all of the provinces of Category I are located in southern China, where climatic conditions are not suitable for the cultivation of wheat but are suitable for that of rice. As illustrated in Fig. 8, the wheat planting area and output of Category I account for only 3.5 and $1.1 \%$, respectively, of the amounts nationally. This category contributes to

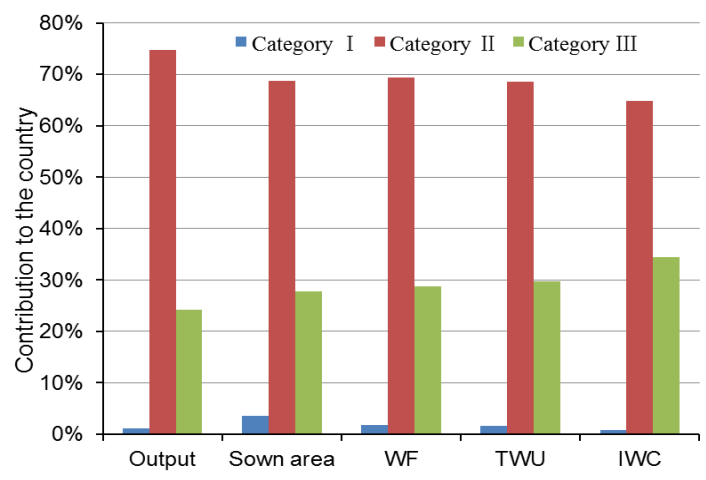

Figure 8. Contributions of three categories to the wheat production indicators.

$1.8 \%$ of the water footprint, $1.6 \%$ of the total water use and only $0.8 \%$ of the irrigation water capacity to the whole country. Therefore, reducing the water investment of wheat production makes is not necessary to increase the wheat yield or relieving the water resource pressure in China. Moreover, the crop yield of this category was only $2.4 \mathrm{tha}^{-1}$, significantly lower than that of other regions. It is unrealistic to depend on these areas to produce more wheat in China.

The calculated QY and QU were 2.83 and 0.96 in Category II. Irrigation conspicuously increases the yield yet hardly reduces the water footprint. This category, which encompasses all of the major wheat-producing areas in the North China Plain, safeguards China's food security. In 2010, $68.7 \%$ of the sown area, $74.7 \%$ of the total output, $69.4 \%$ of the water footprint, $68.6 \%$ of the total water use and $64.8 \%$ of the irrigation water capacity of wheat production across the country are contributed by Category II. The WFP and TWUP in this category were 0.899 and $1.165 \mathrm{~m}^{3} \mathrm{~kg}^{-1}$, less than the national average. Therefore, producing more wheat in this category is instrumental to promoting the country's water-use efficiency. In reality, however, with an annual per capita water resource volume of approximately $400 \mathrm{~m}^{3}$, the North China Plain is one of the most water-deficient regions of China; in addition, water pollution is also a serious issue facing these provinces. Effective measures, such as adopting water-conserving irrigation technology to promote irrigation efficiency, should be taken to protect agricultural production from the effects of water crisis.

The QY in Category III was 2.57, indicating that the crop yield could be increased by $157 \%$ when wheat is irrigated. The QU increases up to 1.42 , indicating plenty of water waste during wheat production. This category contributes to $24.4 \%$ of the output, $28.8 \%$ of the water footprint, $29.8 \%$ of the total water use and $34.4 \%$ of the irrigation water to China's total. The provinces with high QY and QU values belong to Category III and are located in droughty northwestern China, whereby massive irrigation water is demanded to withdraw due to scarce rainfall. In the meantime, the irrigation efficiency is low (no more than 0.500 ), resulting in 
a large amount of water waste in irrigated farmland. With these two drawbacks, this category is not suitable for producing irrigated wheat as far as the water efficiency is concerned. However, this category is essential for China's food security due to a few advantages. The climatic condition with sufficient sunlight and heat is conducive to crop growth, and the provinces in Category III together produce nearly onequarter $(24.2 \%)$ of the national wheat production. In addition, the total water use per kilogram of wheat in the total and irrigated farmlands is 1.522 and $1.618 \mathrm{~m}^{3} \mathrm{~kg}^{-1}$ (Table 4), much higher than that of Category II and the national average. The proportions of blue water use for percolation in some provinces of Category II, are very high, such as in Ningxia (42.5\%), Neimenggu (36.3\%), Xinjiang (34.9\%) and Qinghai $(31.7 \%)$. These high WPF and $\mathrm{BW}_{\mathrm{p}}$ proportions signify a great water saving potential. The irrigation efficiency should be improved further, and the blue water footprints should be reduced for water conservation and to increase production.

\section{Conclusions}

Studies of the crop water footprint at a macroscale (global or national) frequently suffer from limitations in terms of data availability and quality. By distinguishing between the irrigated and rainfed crops, the contribution of this study is the utilisation of the actual statistical data from typical irrigation districts and the calculation of the crop water footprint and the total water use at the regional scale. The major findings of the current study are as follows: (i) the green water related to China's wheat production plays a dominant role in the water footprint, while it is roughly equal to the blue water footprint in the total water use; (ii) a large portion of the water footprint is depleted during delivery and cannot be reused during the crop growth period; and (iii) irrigation increases the crop yield and reduces the water footprint per kilogram of wheat product dramatically, also indicating that more water resources need to be invested in crop production, leading to the total water per unit of irrigated wheat being greater than that of rainfed crops. It is important to compare the water productivity (water use per unit of product) between the irrigated and rainfed farmlands only when the water utilisation is assessed on the regional scale.

This study agrees with previous studies in terms of the importance of green water in China's wheat production, especially for field evapotranspiration (consumption water use). Compared to rainfed crops, obtaining the double benefits of increasing the yield and conserving water in irrigated land is an unattainable objective for some arid provinces. The calculated result is compared to the measured water productivity and virtual water values from previous studies. It is difficult to attribute differences in the estimates from various studies to specific factors and to assess the quality of our new estimates relative to the quality of previous estimates. The data authenticity defines the accuracy of the water footprint calculation result. In this study, we collected a large amount of data regarding agricultural production, and we tried to determine a water footprint value as close to the actual value as possible. An unavoidable drawback of this study is that the water footprint we estimated is only for the representative year. Decision making requires long-term serial historic data sets of actual data and of high quality. Databases regarding agricultural production should be built by the government in the future in cooperation with scientific and technological workers.

Acknowledgements. This work is jointly supported by the Special Foundation of National Science \& Technology Supporting Plan (2011BAD29B09), 111 Project (no. B12007) and the Scholarship Award for Excellent Doctoral Student granted by Ministry of Education (2012). We specially appreciate Jianqiang $\mathrm{He}$ from Northwest A \& F University and Jiaoying Zhu from Xi'an International Studies University, who have checked the language for the paper. We acknowledge Fuqiang Tian for constructive comments and guidance through the review process. Last but not least, we would like to thank two anonymous reviewers for very constructive comments that helped to improve the manuscript.

Edited by: F. Tian

\section{References}

Aldaya, M. M. and Hoekstra, A. Y.: The water needed for Italians to eat pasta and pizza, Agr. Syst., 103, 351-360, 2010.

Aldaya, M. M., Allan, J. A., and Hoekstra, A. Y.: Strategic importance of green water in international crop trade, Ecol. Econ., 69, 887-894, 2010.

Allen, R. G., Pereira, L., Raes, S., and Smith, D.: Crop evapotranspiration- guidelines for computing crop water requirements, FAO irrigation and drainage paper, vol. 56, FAO - Food and Agriculture Organization of the United Nations, Rome, 1998.

Cao, X., Wu, P., Wang, Y., Zhao, X., and Liu, J.: Analysis on temporal and spatial differences of water productivity in irrigation districts in China, T. Chin. Soc. Agr. Eng., 28, 1-7, 2012.

Cao, X., Wu, P., Wang, Y., and Zhao, X.: Temporal and spatial variation and correlativity of water productivity indexes in irrigated land of China, Adv. Water Sci., 25, 268-274, 2014.

Chapagain, A. K., Hoekstra, A. Y., and Savenije, H. H. G.: Water saving through international trade of agricultural products, Hydrol. Earth Syst. Sci., 10, 455-468, doi:10.5194/hess-10-4552006, 2006.

Chen, Y., Guo, G., Wang, G., Kang, S., Luo, H., and Zhang, D.: Main crop water requirement and irrigation of China, Hydraulic Publisher, Beijing, China, 1995.

CMA - China Meteorological Administration: China meteorological data sharing service system, Beijing, China, available from: http://cdc.cma.gov.cn/, last access: October 2011.

Doorenbos, J. and Kassam, A. H.: FAO irrigation and drainage paper No. 33 "Yield response to water", FAO - Food and Agriculture Organization of the United Nations, Rome, 1979. 
Duan, A., Sun, J., Liu, Y., Xiao, J., Liu, Q., and Qi, X.: The irrigating water quota for main crops in north of China, China's Agricultural Science and Technology Press, Beijing, China, 2004.

FAO: CropWat 8.0, edited, land and water development division. Food and Agriculture Organization of the United Nations, Rome, 2009.

Ge, L., Xie, G., Li, S., Zhang, C., and Chen, L.: A study on production water footprint of winter-wheat and maize in the North China Plain, Resour. Sci., 32, 2066-2071, 2010.

Ge, L., Xie, G., Zhang, C., Li, S., Qi, Y., Cao, S., and He, T.: An evaluation of China's water footprint, Water Resour. Manage., 25, 2633-2647, 2011.

Hoekstra, A. Y. (Ed.): Virtual water trade: Proceedings of the International Expert Meeting on Virtual Water Trade, 12-13 December 2002, Delft, the Netherlands, Value of Water Research Report Series No. 12, available at: www.waterfootprint.org/Reports/ Report12.pdf, UNESCO-IHE, Delft, the Netherlands, 2003.

Hoekstra, A. Y. and Chapagain, A. K.: Water footprints of nations: water use by people as a function of their consumption pattern, Water Resour. Manage., 21, 35-48, 2007.

Hoekstra, A. Y. and Chapagain, A. K.: Globalization of water: Sharing the planet's freshwater resources, Blackwell Publishing, Oxford, UK, 2008.

Hoekstra, A. Y. and Hung, P. Q.: Globalisation of water resources: International virtual water flows in relation to crop trade, Global Environ. Change, 15, 45-56, 2005.

Hoekstra, A. Y., Chapagain, A. K., Aldaya, M. M., and Mekonnen, M. M.: The water footprint assessment manual: Setting the global standard, Earthscan, London, UK, 2011.

Li, D.: The farmland water conservancy project planning and design manual, Water Power Press, Beijing, China, 2006.

Liao, Y.: China' s irrigation for food security, China Water Power Press, Beijing, China, 2005.

Liu, J.: Consumptive water use in cropland and its partitioning: A high-resolution assessment, Sci. China Ser. E, 52, 309-3314, 2009.

Liu, J., Williams, J. R., Zehnder, A. J. B., and Yang, H.: GEPIC - modeling wheat yield and crop water productivity with high resolution on a global scale, Agr. Syst., 94, 478-493, 2007a.

Liu, J., Wiberg, D., Zehnder, A. J. B., and Yang, H.: Modelling the role of irrigation in winter wheat yield and crop water productivity in China, Irrigat. Sci., 26, 21-33, 2007b.

Liu, J., Alexander, J. B., and Hong, Y.: Historical trends in China's virtual water trade, Water Int., 32, 78-90, 2007c.
Mekonnen, M. M. and Hoekstra, A. Y.: A global and high-resolution assessment of the green, blue and grey water footprint of wheat, Hydrol. Earth Syst. Sci., 14, 1259-1276, doi:10.5194/hess-141259-2010, 2010.

Mekonnen, M. M. and Hoekstra, A. Y.: The green, blue and grey water footprint of crops and derived crop products, Hydrol. Earth Syst. Sci., 15, 1577-1600, doi:10.5194/hess-15-15772011, 2011.

MWR - Ministry of Water Resource People's Republic of China: Code for design of irrigation and drainage engineering BG50288-99, China Water Power Press, Beijing, China, 1999.

MWR - Ministry of Water Resource People's Republic of China: China Water Resources Bulletin 2010, Water Power Press, Beijing, China, 2011.

NBSC - National Bureau of Statistics of China: China statistical yearbook 2011, China Statistical Press, Beijing, China, 2011.

Perry, C.: Water footprints: Path to enlightenment, or false trail?, Agr. Water Manage., 134, 119-125, 2014.

Playan, E. and Mateos, L.: Modernization and optimization of irrigation systems to increase water productivity, Agr. Water Manage., 80, 100-116, 2006.

Siebert, S. and Döll, P.: Quantifying blue and green virtual water contents in global crop production as well as potential production losses without irrigation, J. Hydrol., 384, 198-207, 2010.

Sun, S., Wu, P. T., Wang, Y., and Zhao, X.: The virtual water content of major grain crops and virtual water flows between regions in China, J. Sci. Food Agr., 93, 1427-1437, 2012.

Sun, S., Wu, P. T., Wang Y., Zhao, X., Liu, J., and Zhang X.: The impacts of interannual climate variability and agricultural inputs on water footprint of crop production in an irrigation district of China, Sci. Total Environ., 444, 498-507, 2013.

Tian, Y., Zhu, D., Wang, H., and Zang, M.: Water footprint calculation of China's main food crops: 1978-2010, China Population, Resour. Environ., 23, 122-128, 2013.

Wu, P., Jin, J., and Zhao, X.: Impact of climate change and irrigation technology advancement on agricultural water use in China, Climatic Change, 100, 797-805, 2010.

Xu, C., Huang, J., Ridoutt, B. G., Liu, J., and Chen, F.: LCA-based product water footprinting and a case study, J. Nat. Resour., 28, 873-880, 2013.

Zhang, L.: Regional diversity of Virtual Water and water footprint in China, Liaoning Normal University, Dalian, 2009. 